\title{
Factors Affecting Growers' Willingness to Adopt Sustainable Floriculture Practices
}

\author{
Tanya J. Hall ${ }^{1}$ \\ Department of Agricultural Economics, Purdue University, 403 West State \\ Street, West Lafayette, IN 47907
}

Jennifer H. Dennis ${ }^{2,5}$

Departments of Agricultural Economics and Horticulture and Landscape Architecture, Purdue University, 625 Agriculture Mall Drive, West Lafayette, IN 47907

\author{
Roberto G. Lopez ${ }^{3}$ \\ Department of Horticulture and Landscape Architecture, Purdue University, \\ 625 Agriculture Mall Drive, West Lafayette, IN 47907
}

\author{
Maria I. Marshall ${ }^{2,4}$ \\ Department of Agricultural Economics, Purdue University, 403 West State \\ Street, West Lafayette, IN 47907
}

Additional index words. attitudes, environmental regulations, greenhouse, grower perceptions, logistic regression, risk, social capital, survey

\begin{abstract}
In June to Oct. 2008, a U.S. floriculture survey was conducted to examine the factors affecting growers' willingness to adopt sustainable practices. The factors affecting adoption of sustainable practices were evaluated in five areas: environmental regulations, customer value, growers' attitudes toward sustainability, age, and operation size. A logistic regression model was used to examine factors affecting growers' adoption of sustainable practices. Nearly two-thirds $(65.2 \%)$ of respondents thought sustainability was very important to the environment. Similarly, more than half $(63 \%)$ of the respondents had sustainable practices in their operations. Although respondents had positive attitudes toward sustainability and the environment, these positive attitudes alone were unable to predict adoption behaviors. The two most important factors that affected adoption of sustainable practices were the concerns about implementation and the risk perceived by growers. Neither perceived customer value nor the stringency of state regulations affected the adoption of sustainable practices. The results from this study provide original insight into growers' views of sustainability and identify the educational assistance needed by growers to overcome the factors affecting their adoption of sustainable practices.
\end{abstract}

The commercial floriculture industry in the United States includes bedding and garden plants, potted flowering and foliage plants, propagative material, cut flowers, and cut cultivated greens (USDA, 2008). According to the 2007 Census of Agriculture, floriculture crops were grown at 26,236 operations

Received for publication 28 Apr. 2009. Accepted for publication 2 June 2009

We gratefully acknowledge funding from Ball Horticultural Company and Purdue University's Mission Oriented Grant, growers providing support for Purdue University floriculture research, and numerous state associations and trade press who promoted the survey.

${ }^{1}$ Masters student.

${ }^{2}$ Associate Professor.

${ }^{3}$ Assistant Professor.

${ }^{4}$ Current address: Purdue University, Department of Horticulture and Landscape Architecture, 625 Agriculture Mall Drive, West Lafayette, IN 47907.

${ }^{5}$ To whom reprint requests should be addressed; e-mail jhdennis@purdue.edu. crops can cause a greenhouse operation to negatively affect the environment, thus spurring discussions about sustainability in the floriculture industry (Krug et al., 2008; Stewart, 2007).

The Floriculture Sustainability Research Coalition defines sustainable floriculture production as aiming to reduce environmental degradation, maintaining agricultural productivity, promoting economic viability, conserving resources and energy, and maintaining stable communities and quality of life (Krug et al., 2008). Examples of sustainable practices include recycling irrigation water and plastic, implementing biological controls, and using alternative energy sources (Lopez et al., 2008). According to an informal survey conducted by Greenhouse Grower (2008), the top 100 U.S. growers indicated conflicting opinions about sustainability and its role in the floriculture industry. Some growers felt the industry should progress toward sustainable production practices, whereas other growers felt they already took care of the environment (Tambascio, 2008). Growers were also concerned about the consumer's perception of sustainable floriculture and growers question the benefits they will receive from adopting sustainable practices (Tambascio, 2008). These responses to sustainability indicate that research is needed to better understand what influences growers' decisions to adopt sustainable practices in their operation.

The objective of this research was to identify factors influencing growers' willingness to adopt sustainable floriculture production practices. "Willingness to adopt" refers to a grower's motivation to adopt a new innovation, technology, and/or practice in their business (Anderson, 1993). Research in other agricultural industries was used to identify factors that influence growers' adoption of new practices because to date, there are no peer-reviewed articles on growers' perceptions of sustainable floriculture practices.

\section{Review of Literature}

with sales receipts of nearly $\$ 6.5$ billion (USDA, 2009).

Floriculture crop production is inputintensive and requires the use of nonrenewable and petroleum-based products for pesticides, fertilizers, growth regulators, heating, greenhouse glazing, and packaging to make the crop uniform and of consistent high quality (Krug et al., 2008; Lopez et al., 2008). Most of these crops are produced under 819 million square feet $(18,823$ acres $)$ of controlled greenhouse environments or protected structures (USDA, 2008, 2009). These crops are commonly grown in nonrecyclable plastic containers that are often disposed of by consumers and landscapers, thus presenting a significant disposal issue for the horticulture industry (Evans and Hensley, 2004). Garthe and Kowal (1993) estimated at least 408 million pounds of plastic are generated for use in the nursery and floriculture industry and this number is expected to grow. Petroleumbased products used to produce floriculture
Adoption. Adoption is a mental process that begins when an individual or operation learns of an innovation and ends at the final adoption stage (Rogers, 1962). Numerous studies were conducted to better understand the factors that influence adoption of conservation and organic production practices (e.g., Barreiro-Hurle et al., 2008; Baynard and Jolly, 2007). These studies found that factors influencing growers' willingness to adopt new practices depend on industry-situational factors such as the degree of environmental regulation, customer-perceived value of the practice in question, grower attitudes toward the practice, and grower demographic characteristics.

Environmental regulations. Environmental regulations are environmental laws imposed by state and federal governments on agricultural industries (Isik, 2004). States can choose to set their regulations higher than the federal standard or keep it status quo with federal guidelines (Isik, 2004; Kraft and Vig, 1994; Lester, 1994). Several studies have 
examined the degree of environmental stringency on various agricultural production practices (Kara et al., 2006; Metcalfe, 2000; Mo and Abdalla, 1998). Kara et al. (2006) examined the adoption of environmentalquality protection management practices such as erosion plans, grassed waterways, filter strips, and nutrient testing among corn growers operating in states with strict regulations and found an increase in adoption of best management and conservation practices. Therefore, growers operating in environmentally stringent states may be influenced to adopt best management practices, including sustainable practices.

Customer value. Customer value is the consumer's overall assessment of the usefulness of a product based on perceptions of what is received and what is given (Zeithamal, 1988). Typically, customer value is perceived by the customer, not predetermined by the seller or grower of the product (Woodruff, 1997). These perceptions usually involve a tradeoff between what the customer receives (e.g., quality, benefits, worth, usefulness) and what they give up to acquire and use a product (e.g., money, time, sacrifices) (Woodruff, 1997). As growers consider adoption of sustainable practices, if they find positive customer value tradeoffs exist for sustainable practices, they may be more willing to adopt sustainable practices. Thus, positive customer value for sustainable practices may affect growers' willingness to adopt sustainable practices.

Attitudes of growers. Past studies have found positive relationships between growers' attitudes, perceptions, and social capital levels toward the environment and participation in environmental programs (Barreiro-Hurle et al., 2008; Baynard and Jolly, 2007; Jordan, 2005). Baynard and Jolly (2007) found cereal growers' perceptions of susceptibility to environmental degradation was a factor in shaping their attitudes and, indirectly, their environmental actions. Barreiro-Hurle et al. (2008) and Jordan (2005) found that higher levels of social capital positively influenced growers' attitudes and perceptions toward participation in environmental programs. Social capital is defined as a person's sense of empathy and ethical obligation toward other persons or groups, known as "doing the right thing" (Jordan, 2005). Likewise, several certified sustainable floriculture growers stated their reason for adopting sustainable practices as being the "right thing to do" and their responsibility as business owners [Anonymous. Conversations with Veriflora ${ }^{\circledR}$ certified growers (phone calls), personal communication, 26 Feb. to 19 Mar. 2008].

However, the Theory of Planned Behavior (TPB) states that attitudes alone are not sufficient to predict behavior because social pressures and the perceived difficulty in carrying out the action are also important factors (Hattam, 2006). The TPB was upheld in two studies in which positive attitudes alone were poor predictors of behavior in the adoption of organic agriculture and the influence of environmental attitude toward ecological behavior (Hattam, 2006; Kaiser et al., 1999). Hattam (2006) found that avocado growers' perceived ability of themselves to successfully adopt an organic production system was an important influence on their intentions. Growers who had negative perceptions about their abilities were less likely to adopt sustainable practices, although they understood its importance and had environmental concerns (Hattam, 2006). Consequently, growers with negative attitudes and perceptions about sustainability, negative perceptions of their abilities, or have low levels of social capital may be less likely to adopt sustainable practices.

Demographics. Previous studies have examined the role of age and operation size on adoption. Three studies found that adoption of new practices such as conservation programs and organic production were negatively influenced by an increase in the grower's age, yet positively influenced by education levels (Barreiro-Hurle et al., 2008; D'Souza et al., 1993; Hattam, 2006). Growers 54 years or older were less likely to adopt new conservation and organic practices unless it involved minimal labor and did not need new investments in capital or knowledge (Barreiro-Hurle et al., 2008; D’Souza et al., 1993; Hattam, 2006). Conflicting results were reported in past studies that examined the effects of operation size on adoption of environmentally friendly programs (Bonnieux et al., 1998; D'Souza et al., 1993; Wilson, 1997). Therefore, it is expected that among floriculture growers, growers older than 54 years are less likely to adopt sustainable practices and operation size will not affect adoption of sustainable practices.

Based on literature examining environmental stringency, customer value, attitudes, and demographics, five hypotheses were formed. Commercial greenhouse growers who operate in environmentally strict states (water and chemical regulations) are more likely to adopt sustainable practices $\left(\mathrm{H}_{1}\right)$. Growers with market segments that value sustainability are more likely to adopt sustainable practices $\left(\mathrm{H}_{2}\right)$. Growers with negative attitudes about sustainability are less likely to adopt sustainable practices $\left(\mathrm{H}_{3}\right)$. Growers older than 54 years are less likely to adopt sustainable practices $\left(\mathrm{H}_{4}\right)$. Operation size will not have an effect on a grower's adoption of sustainable practices $\left(\mathrm{H}_{5}\right)$.

\section{Materials and Methods}

A national convenience sample of U.S. floriculture growers was surveyed between June and Oct. 2008. Two identical surveys were administered by paper and the Internet. The multiple outreach methods were developed to improve response rates of the survey because research shows repeated contacts improve response rates (Dillman, 2007). The paper survey was distributed to floriculture growers at the 2008 Ohio Florist Association (OFA) Short Course, DS Cole Growers open house, and at the Indiana Floriculture Growers Association annual conference. The Internet version of the survey was promoted at OFA and to horticultural associations to increase grower response, thus providing another convenient way to complete the questionnaire. A total of 86 horticultural associations in 46 states were contacted to assist in promoting the survey to their members, and 16 states assisted in the promotion. Two states (Indiana and California) provided addresses for their members, and the questionnaire was mailed to these growers. Floriculture trade press was also contacted and brief articles were run to promote the survey. Trade press outlets included: Ball Publishing GreenTalks, Greenhouse Grower Benchrunner, Greenhouse Management and Production (GmPro) Project: Green Industry, and Greenhouse Product News (GPN) weekly. These trade press outlets were chosen because they are the major trade press outlets in the floriculture industry and widely read by growers.

The questionnaire was developed by the researchers and included a Likert scale, rank order, and open-ended questions based on the floriculture industry's priorities and an extensive literature search. It asked respondents about the importance of sustainability, views of state environmental regulations, sustainable practices in place, and sustainable practices they would like to implement in the future. Questions concerning their attitudes and perceptions toward profitability, risk, and obstacles to adoption were also asked. Respondents were asked to report their square footage, gross sales, number of employees, crops grown, customer groups, years in the floriculture industry, age, educational level, and zip code. In total, 112 surveys were collected and used for analysis in SPSS 16.0 (SPSS Inc., Chicago, IL).

For this study, a binary logistic regression was used to regress the dependent variable, y, of whether the grower had adopted sustainable practices,

$$
y=\left\{\begin{array}{l}
1: \text { adopted } \\
0: \text { otherwise },
\end{array}\right.
$$

against the estimated factors affecting adoption of sustainable practices variables (Liao, 1994). The parameter estimates $(\beta)$ predict the log odds (logit) of the dependent variable (y). Thus, the prediction equation is (Garson, 2009):

$$
y=\operatorname{In}(\text { odds }(\text { event }))
$$

$$
\begin{aligned}
& =\operatorname{In}\left(\frac{\operatorname{prob}(\text { event })}{\text { prob }(\text { nonevent })}\right) \\
& =\operatorname{In} \frac{(\text { prob }(\text { event }))}{[1-\text { prob }(\text { event })]} \\
& =b_{0}+b_{1} X_{1}+b_{2} X_{2}+\cdots+b_{k} X_{k}
\end{aligned}
$$

Thus, the model can be expressed as follows: 


$$
\begin{aligned}
Y= & \beta_{0}+\beta_{1} \text { redstreg }+\beta_{2} \text { stgovcon } \\
& +\beta_{3} \text { stgovr }+\beta_{4} \text { cnovalu }+\beta_{5} \text { custd } \\
& +\beta_{6} \text { custvalu }+\beta_{7} \text { sfimpt }+\beta_{8} \text { sfisfad } \\
& +\beta_{9} \text { skills }+\beta_{10} \text { prodrsk }+\beta_{11} \text { bizresp } \\
& +\beta_{12} \text { risknexp }+\beta_{13} \text { winvest }+\beta_{14} \text { eztoimpl } \\
& +\beta_{15} \text { noinc }+\beta_{16} \text { conflvl }+\beta_{17} \text { didobyr } \\
& +\beta_{18} \text { size }+\beta_{19} \text { educ }+\beta_{20} \text { location }+\varepsilon .(3)
\end{aligned}
$$

Descriptions for each explanatory variable can be found in Table 1 .

\section{Results and Discussion}

Demographic characteristics of floriculture growers and operations. Growers ranged in age from 27 to 72 years old with a mean age of 57 years and were predominantly male $(62.5 \%)$, college graduates $(79.5 \%)$, and white $(92.9 \%)$ (Table 2). Commercial floriculture growers nationwide participated with $48.2 \%$ responding from the Midwest (Table 3). The majority (35.7\%) of growers described their operations as a wholesaler or a grower $(34.6 \%)$ who predominately (28.0\%) grows bedding plants. Growers identified their primary customer group as cash and carry customers $(26.9 \%)$ followed by landscapers, independent garden centers, and other small venues (20.4\%) (Table 3). Twenty-five percent of growers had gross sales of less than $\$ 100,000$ with a median gross sale of $\$ 500,001$ to $\$ 1$ million $(7.1 \%)$ in 2007 (Table 3). The majority (57.1\%) of respondents had a covered greenhouse production area of less than 1 acre (less than 43,560 square feet) with a median size of 30,000 square feet (Table 3).

Knowledge of sustainable floriculture practices. Overwhelmingly, $95.5 \%$ of res- pondents had heard of sustainable floriculture and the majority $(65.2 \%)$ viewed sustainable practices as "very important" to the environment (data not shown). Sixty-three percent of growers had sustainable practices in their operations and $24.3 \%$ were in the process of becoming sustainable. Recycling plastic pots and/or greenhouse glazing materials were the most common sustainable practice in place (72.7\%) followed by water recycling and/or conservation (62.4\%) (Table 4). Ranked in order of importance, growers indicated they wanted to pursue recycling of plastic pots/ greenhouse glazing materials and biological controls followed by conservation of energy, water recycling/conservation, and alternative energy sources (Table 4). Results show that growers had similar ranked priorities in the practices they have already implemented and/or want to implement.

Significant factors affecting willingness to adopt. The binary logistic model regressed whether the grower had adopted sustainable practices as the dependent variable against explanatory variables of environmental regulations, customer value, growers' attitudes, and demographics (Table 1). This model was significant $\left(\chi^{2}=44.45, P=0.003\right)$ correctly predicting $80.0 \%$ of the observations (data not shown). Of the five hypotheses, only $\mathrm{H}_{3}$, growers with negative perceptions about the ease of implementation, potential yield risk, and uncertainty of conversion who are less likely to adopt sustainable practices, was supported (Table 5).

Perception of factors affecting willingness to adopt. Hypothesis $1\left(\mathrm{H}_{1}\right)$ stated commercial greenhouse growers who operate in environmentally strict states are more likely to adopt sustainable practices. Seventeen percent of respondents felt their state had strict water regulations and $\approx 32 \%$ felt their state had strict chemical regulations. Growers' perceptions of their state's environmental regulations (redstreg) had a statistically insignificant effect on growers' willingness to adopt sustainable practices (Table 5). Growers also indicated state regulations were not an important concern when considering adoption of new technologies in their operation (stgovcon and stgovr). These results signify that floriculture growers may not be affected by environmental regulations as much as other agricultural sectors or are ahead of regulators in adopting sustainable practices. Therefore, $\mathrm{H}_{1}$ was not supported.

Hypothesis $2\left(\mathrm{H}_{2}\right)$ stated growers with market segments that value sustainability are more likely to adopt sustainable practices. Growers' perceptions of whether customers value sustainable production practices (custvalu) was insignificant (Table 5). Growers indicated that customer demand (custd) was not a primary consideration when adopting new technologies. Therefore, $\mathrm{H}_{2}$ was not supported. The insignificant results may indicate that growers do not feel their customers recognize the additional benefits from sustainably grown plants nor are they willing to trade off for the additional benefits. Woodruff (1997) stated that customer value is perceived by the customer and cannot be predetermined by the grower. In this scenario, growers and consumers may be subconsciously attaching different values on sustainable practices. It is interesting that growers did not rank customer demand as an important consideration in the adoption of sustainable practices when growers have voiced concerns about sustainability being a mass merchandiser push versus an end customer demand pull approach (Tambascio, 2008).

Hypothesis $3\left(\mathrm{H}_{3}\right)$ stated growers with negative perceptions about sustainability

Table 1. Description of variables used in the logistic regression model.

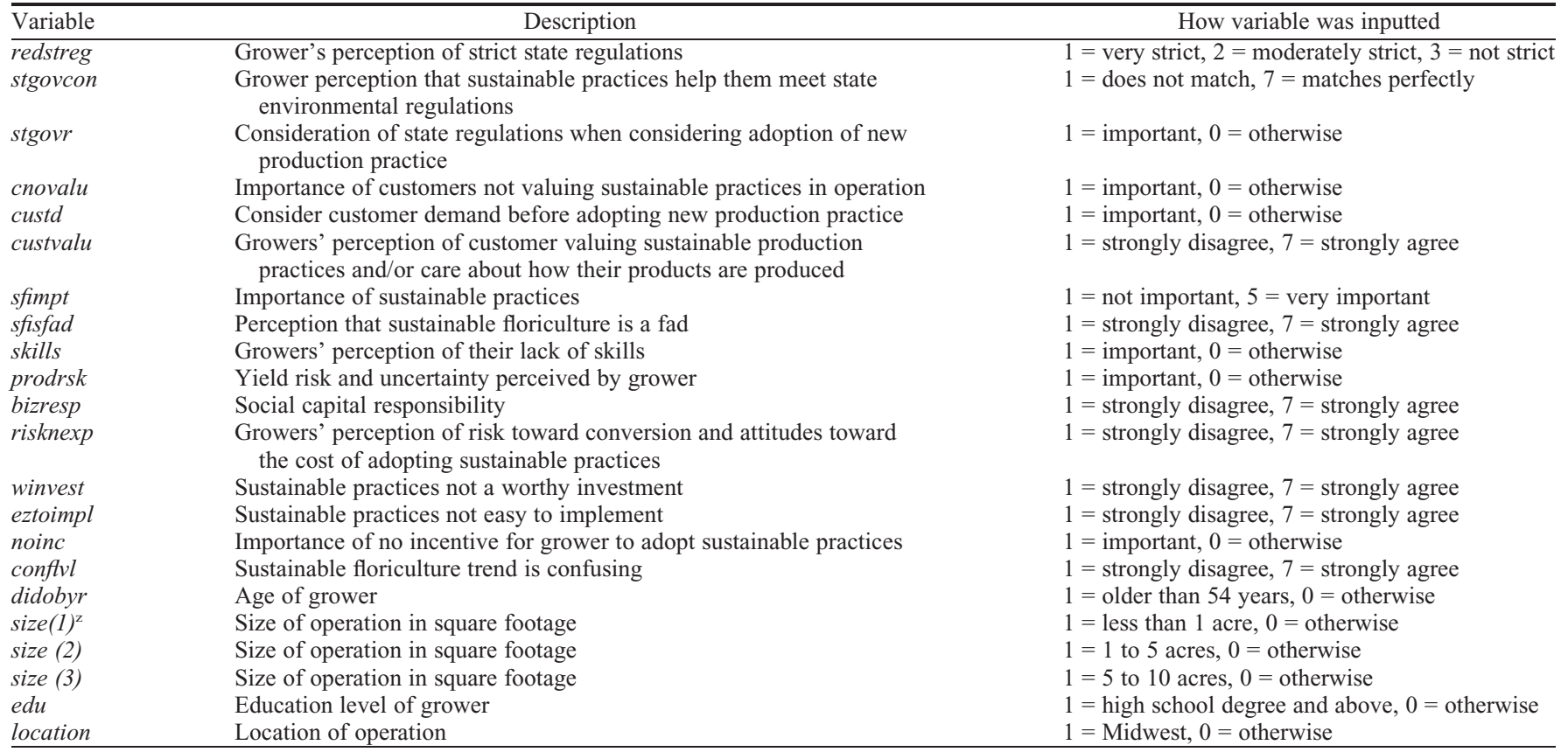

${ }^{{ }^{\text {size }}(4)}=10+$ acres was held as the reference. 
Table 2. Demographic characteristics of respondents.

\begin{tabular}{lrr}
\hline & $\begin{array}{c}\text { Number of } \\
\text { respondents }\end{array}$ & (\%) \\
\hline Age of respondents (years) & & \\
70 to 79 & 4 & 3.6 \\
60 to 69 & 10 & 8.9 \\
50 to 59 & 45 & 40.2 \\
40 to 49 & 24 & 21.4 \\
30 to 39 & 18 & 16.1 \\
20 to 29 & 6 & 5.3 \\
Did not respond & 5 & 4.5 \\
Sex & & \\
Male & 70 & 62.5 \\
Female & 39 & 34.8 \\
Did not respond & 3 & 2.7 \\
Education level & & \\
High school graduate & 5 & 4.5 \\
Some college & 16 & 14.2 \\
College graduate & 64 & 57.1 \\
Masters degree & 18 & 16.1 \\
Doctoral degree & 7 & 6.3 \\
Did not respond & 2 & 1.8 \\
Ethnicity & & \\
African & 1 & 0.9 \\
White or European & 104 & 92.9 \\
Asian & 1 & 0.9 \\
Other & 3 & 2.7 \\
Did not respond & 3 & 2.7 \\
\hline
\end{tabular}

were less likely to adopt sustainable practices. The perceived importance of sustainability to the environment (sfimpt) $(P=0.014)$, perceived grower risk in adopting sustainable practices (prodrsk) $(P=0.027)$, and implementation ease of sustainable practices (eztoimpl $)(P=0.015)$ were statistically significant (Table 5). The results show that for each 1-point increase in the grower's view of sustainability as important to the environment, the odds of adopting sustainable practices increases 13 times. However, with increases in growers' perceptions of risk, including potential yield loss and uncertainty of conversion, the adoption odds decrease 0.361 times. If a grower perceives adopting sustainable practices as difficult, the odds of adopting sustainable practices decrease 0.253 times. Therefore, $\mathrm{H}_{3}$ was supported.

The grower's perception that sustainability is important to the environment was significant and consistent with previous studies that found a positive relationship between growers' attitudes and perceptions toward the environment and participation in environmental programs (e.g., Barreiro-Hurle et al., 2008; Baynard and Jolly, 2007; Jordan, 2005). Growers were asked questions about social capital on a 7-point Likert scale and demonstrated high levels of social capital (data not shown). Although the social capital variables were insignificant, its trend was consistent with previous findings (Barreiro-Hurle et al., 2008; Jordan, 2005). In this study, attitudes alone were unable to predict growers' behaviors because growers had negative perceptions about sustainable practices' ease of implementation in their operations, which is similar to the findings by Kaiser et al. (1999) and Hattam (2006).

The fourth hypothesis $\left(\mathrm{H}_{4}\right)$ stated that growers older than 54 years are less likely to adopt sustainable practices. The variable

Table 3. Demographic characteristics of the respondents' operation.

\begin{tabular}{|c|c|c|}
\hline & $\begin{array}{l}\text { Number of } \\
\text { respondents }\end{array}$ & $(\%)$ \\
\hline \multicolumn{3}{|l|}{ Region } \\
\hline Northeast & 13 & 11.6 \\
\hline Midwest & 54 & 48.2 \\
\hline South & 17 & 15.2 \\
\hline West & 17 & 15.2 \\
\hline Did not respond & 11 & 9.8 \\
\hline \multicolumn{3}{|l|}{ Size (gross sales) } \\
\hline Less than $\$ 100,000$ & 28 & 25.0 \\
\hline$\$ 100,001$ to 250,000 & 15 & 13.4 \\
\hline$\$ 250,001$ to 500,000 & 7 & 6.3 \\
\hline$\$ 500,001$ to 1 million & 8 & 7.1 \\
\hline$\$ 1,000,001$ to 2 million & 12 & 10.7 \\
\hline$\$ 2,000,001$ to 5 million & 11 & 9.8 \\
\hline$\$ 5,000,001$ to 10 million & 9 & 8.0 \\
\hline$\$ 10,000,001$ to 20 million & 11 & 9.8 \\
\hline Greater than $\$ 20$ million & 5 & 4.5 \\
\hline Did not respond & 6 & 5.4 \\
\hline \multicolumn{3}{|l|}{ Size (square footage converted to acres) } \\
\hline 0 to 1 acres & 64 & 57.1 \\
\hline 1 to 5 acres & 13 & 11.6 \\
\hline 5 to 10 acres & 13 & 11.6 \\
\hline $10+$ acres & 15 & 13.4 \\
\hline \multirow[t]{2}{*}{ Did not respond } & 7 & 6.3 \\
\hline & Mean & SD \\
\hline \multicolumn{3}{|l|}{ Operation type ${ }^{z}$} \\
\hline Percent as wholesaler & 35.7 & 40.7 \\
\hline Percent as grower & 34.6 & 39.2 \\
\hline Percent as retailer & 23.8 & 32.2 \\
\hline \multicolumn{3}{|l|}{ Customer type $^{z}$} \\
\hline Percent cash and carry & 26.9 & 38.9 \\
\hline Percent landscapers/independent garden center & 20.4 & 31.9 \\
\hline Percent wholesale retailers & 14.7 & 27.1 \\
\hline Percent other growers & 8.0 & 39.2 \\
\hline Percent mass merchandisers & 7.8 & 22.0 \\
\hline Percent retail florists & 6.3 & 17.8 \\
\hline \multirow[t]{2}{*}{ Percent supermarket chains } & 5.6 & 15.6 \\
\hline & Mean & SD \\
\hline \multicolumn{3}{|l|}{ Crops grown ${ }^{z}$} \\
\hline Percent bedding plants & 28.0 & 28.9 \\
\hline Percent container perennials & 16.4 & 24.2 \\
\hline Percent flowering potted plants & 16.1 & 24.0 \\
\hline Percent fresh cut flowers & 10.5 & 28.0 \\
\hline Percent plugs and propagation & 8.3 & 18.8 \\
\hline Percent shrubs and woody ornamentals & 7.4 & 19.6 \\
\hline Percent vegetables & 4.1 & 8.2 \\
\hline Percent herbs & 3.9 & 8.4 \\
\hline Percent potted foliage & 3.0 & 9.9 \\
\hline Percent other & 1.4 & 24.3 \\
\hline
\end{tabular}

${ }^{\mathrm{z}}$ Growers ranked all categories that applied to operation.

Table 4. Responses of growers current and future sustainable production practices by percentage and rank $(1=$ very important to $13=$ least important $)$.

\begin{tabular}{lcc}
\hline Sustainable practice & $\begin{array}{c}\text { Currently in } \\
\text { place }^{z}(\%)\end{array}$ & $\begin{array}{c}\text { Would like to } \\
\text { implement }^{\mathrm{y}}(\mathrm{median})\end{array}$ \\
\hline Recycling plastic pots and/or greenhouse glazings & 72.7 & 4.0 \\
Water recycling and/or conservation & 62.4 & 4.5 \\
Conservation/efficiency of energy & 58.2 & 4.0 \\
Composting & 57.3 & 7.0 \\
Biological controls & 56.9 & 4.0 \\
Energy curtains & 39.1 & 5.5 \\
Use of organic fertilizer & 27.3 & 6.0 \\
Chemical runoff protection & 26.4 & 7.0 \\
Biodegradable pots & 22.7 & 6.0 \\
Alternative media & 19.1 & 7.0 \\
Alternative energy sources & 16.5 & 5.0 \\
Other & 13.6 & 10.0
\end{tabular}

${ }^{\mathrm{z}}$ Growers were asked to indicate all sustainable practices that they had in place.

${ }^{y}$ Growers were asked to rank the practices they would like to implement in their operation.

didobyr was statistically insignificant and has no effect on adoption of sustainable practices. This result differs from previous studies that found growers older than 54 years have a tendency to not adopt new technologies (Barreiro-Hurle et al., 2008; D'Souza et al., 1993; Hattam, 2006). Therefore, $\mathrm{H}_{4}$ was not supported. 
Table 5. Regression coefficients of logistic regression model.

\begin{tabular}{|c|c|c|c|c|}
\hline Variables $^{\mathrm{z}}$ & $\begin{array}{c}\text { Estimated } \\
\text { coefficient }(\beta)\end{array}$ & SE & $\mathrm{P}\{|\mathrm{Z}|\}>\mathrm{Z}$ & $\begin{array}{c}\text { Odds ratio of } \\
\text { adopting }^{\mathrm{y}}\end{array}$ \\
\hline Constant & -12.082 & 5.795 & 0.037 & 0.000 \\
\hline redstreg & -0.608 & 0.487 & 0.212 & 0.544 \\
\hline stgovcon & -0.051 & 0.261 & 0.845 & 0.950 \\
\hline stgovr & 0.245 & 0.815 & 0.764 & 1.278 \\
\hline cnovalu & 0.374 & 0.965 & 0.699 & 1.453 \\
\hline custd & -1.122 & 0.798 & 0.160 & 0.326 \\
\hline custvalu & 0.156 & 0.493 & 0.752 & 1.168 \\
\hline sfimpt** & 2.585 & 1.047 & 0.014 & 13.267 \\
\hline sfisfad & -0.170 & 0.523 & 0.745 & 0.844 \\
\hline skills & -0.953 & 1.001 & 0.341 & 0.385 \\
\hline prodrsk** & -1.019 & 0.460 & 0.027 & 0.361 \\
\hline bizresp & 1.010 & 0.645 & 0.117 & 2.745 \\
\hline risknexp & 0.102 & 0.443 & 0.817 & 1.108 \\
\hline winvest & -0.079 & 0.376 & 0.833 & 0.924 \\
\hline eztoimpl** & -1.375 & 0.564 & 0.015 & 0.253 \\
\hline noinc & 0.949 & 0.896 & 0.289 & 2.584 \\
\hline conflvl & 0.223 & 0.210 & 0.288 & 1.249 \\
\hline didobyr & 0.151 & 0.828 & 0.855 & 1.163 \\
\hline size (1) & -0.429 & 1.052 & 0.683 & 0.651 \\
\hline size (2)* & 3.361 & 1.998 & 0.093 & 28.810 \\
\hline size (3) & 2.490 & 1.570 & 0.113 & 12.060 \\
\hline educ & 0.063 & 1.814 & 0.972 & 1.066 \\
\hline location* & 1.552 & 0.908 & 0.087 & 4.722 \\
\hline
\end{tabular}

${ }^{\mathrm{z}} \mathrm{Prob}(\mathrm{Y}=1)$ : adopted sustainable floriculture practices.

${ }^{y}$ Odds ratio is the $\operatorname{Exp}(\beta)$.

**, *Significance level at $P \leq 0.05$ and 0.10 , respectively.

The final hypothesis $\left(\mathrm{H}_{5}\right)$ stated operation size would not have an effect on growers' adoption of sustainable practices. This hypothesis was not supported because size(2) was statistically significant $(P=0.093)$ (Table 5). This indicates that the odds of a grower with an operation between 1 and 5 acres of adopting sustainable practices is 28.81 times greater than a grower with over 10 acres. All other operation sizes were insignificant. This finding is consistent with previous studies that also found operation size had a positive effect on adoption rates of environmentally friendly programs (e.g., Morris and Potter, 1995).

In this model, two other variables (educ and location) were held as constants. Of these constant variables, location was positive and statistically significant $(P=0.087)$ indicating growers in the Midwest are 4.72 times more likely to adopt sustainable practices than other growers in the United States (Table 5). Education levels in this study were found to be insignificant factors on growers' willingness to adopt sustainable practices.

Although these findings represent opinions of 112 growers and cannot be projected to all floriculture operations, at least one of the findings is consistent with marketing principles. This study found smaller operations were more likely to adopt sustainable practices and is consistent with marketing texts that show small businesses can use their size to quickly convert to new technologies and innovations (Scarborough and Zimmerer, 2006). Smaller businesses can use this quick conversion as a core competency, which can lead to a competitive advantage. Small businesses tend to have more flexibility to make changes in their operation, giving them a niche in the marketplace, because they can capture new trends in the industry faster than larger operations.
Although this study showed smaller operations were more likely to convert to sustainable practices, size alone was not the only indicator and other variables did impact whether growers were likely to adopt. For example, growers who had negative perceptions about sustainability were less likely to adopt. These negative perceptions may stem from uncertainty about what constitutes sustainability or the lack of information on new systems once they decide to convert. Growers' negative perceptions may stem from the amount of production risks involved as a result of limited information and the degree to which consumers acknowledge and value sustainably produced crops.

The presence of social capital among the respondents and the lack of impact from environmental regulations appear to indicate that floriculture growers are being proactive in caring for the environment. These growers emphasize that being sustainable helps them take care of the environment, that it is a worthy cause and investment to get involved in, and that it is their responsibility as a business owner. If these attitudes continue, it may be unnecessary for state or federal agencies to implement environmental regulations in this industry in the future, because floriculture growers are being proactive rather than reactive to environmental concerns.

\section{Conclusions}

Growers view sustainability as important to the environment, and these positive attitudes greatly improve adoption rates of sustainable practices. Yet positive attitudes alone were unable to predict a grower's behavior toward sustainability. Growers' concern about the ease of implementation was the most significant factor affecting the adoption of sustainable practices followed by the production risk perceived by growers. The effect of environmental regulations and customer value were insignificant factors on the adoption of sustainable practices. Demographic factors such as the operation's location and size had significant effects on growers' adoption of sustainable practices. Midwest growers with small acreage (1 to 5 acres) had greater odds of adopting sustainable practices than growers who live outside of the Midwest with an operation size greater than 10 acres. Therefore, based on this study, the grower most likely to adopt sustainable practices will be located in the Midwest, have 1 to 5 acres devoted to floriculture production, and exhibit positive attitudes toward the environment and sustainability. Although these findings indicate smaller Midwestern operations will adopt sustainable practices, it must be noted that $68.7 \%$ of respondents had small operation sizes and $48.2 \%$ of respondents were located in the Midwest.

This research provides information useful to growers and industry educators about the current perceptions of sustainability. Based on these findings, growers seek information on the best approach to implementing sustainable practices. Growers need educational assistance from extension personnel as well as industry experts to decrease the production and marketing risk of converting to this newer technology. Showing the benefits of sustainability is also important to help improve customer value for sustainable products.

\section{Literature Cited}

Anderson, J.R. 1993. The economics of new technology adaptation and adoption. Rev. Mktg. Agr. Econ. 61:301-309.

Barreiro-Hurle, J., M. Espinosa-Goded, and P. Dupraz. 2008. Does intensity of change matter? Factors affecting adoption in two agri-environmental schemes. Presented at 107th EAAE Seminar, Seville, Spain, 29 Jan. to 1 Feb. 2008. 12 June 2008. <http://purl.umn.edu/6458>.

Baynard, B. and C.M. Jolly. 2007. Environmental perceptions and behavioral change in hillside farmers: The case of Haiti. J. Caribbean Agro-. Econ. Soc. 7:122-138.

Bonnieux, F., P. Rainelli, and D. Vermersch. 1998. Estimating the supply of environmental benefits by agriculture: A French case study. Environ. Resour. Econ. 11:135-153.

Dillman, D.A. 2007. Mail and Internet surveys: The tailored design method. 2nd Ed. Wiley, Hoboken, NJ.

D’Souza, G., D. Cyphers, and T. Phipps. 1993. Factors affecting the adoption of sustainable agricultural practices. Agr. Resource Econ. Rev. 22:159-165.

Evans, M.R. and D.L. Hensley. 2004. Plant growth in plastic, peat, and processed poultry feather fiber growing containers. HortScience 39:1012-1014.

Garson, G.D. 2009. Logistic regression. 9 Feb. 2009. <http://www2.chass.ncsu.edu/garson/ pa765/statnote.htm>

Garthe, J.W. and P.D. Kowal. 1993. PennState fact sheet C-8. 21 Aug. 2008. <http://www.abe. psu.edu/extension/factsheets/c/C8.pdf>.

Greenhouse Grower. 2008. Standards, certification and sustainability. 2 June 2008. <http:// www.greenhousegrower.com/grower_tools/ 200804_forum.html>.

Hattam, C. 2006. Adopting organic agriculture: An investigation using the Theory of Planned 
Behaviour. Poster presented at Intl. Assn of Agr. Econ. Conference, Gold Coast, Australia, 12-18 Aug. 2006. 2 Mar. 2008. <http://purl.umn.edu/ 25269>.

Isik, M. 2004. Environmental regulation and the spatial structure of the U.S. Dairy Sector. Amer. J. Agr. Econ. 86:949-962.

Jordan, J.L. 2005. Farmer's choice of using sustainable agricultural practices: A social capital approach. Presented at the Southern Agr. Econ. Assn. Annu. Mtg. Little Rock, AR, 6-8 Feb. 2005. 12 June 2008. <http://purl.umn.edu/35505>.

Kaiser, F.G., S. Wolfing, and U. Fuhrer. 1999. Environmental attitude and ecological behavior. J. Environ. Psychol. 19:1-19.

Kara, E., R.C. Johansson, and M. Ribaudo. 2006. On how environmental stringency influences BMP adoption. Presented at Amer. Agr. Econ. Assn. Annu. Mtg. Long Beach, CA, July 2006. 12 June 2008. <http://purl.umn.edu/21207>.

Kraft, M.E. and N.J. Vig. 1994. Environmental policy from the 1970s to the 1990s: Continuity and change, p. 3-29. In: Kraft, M.E. and N.J. Vig (eds.). Environmental policy in the 1990s, Congressional Quarterly, Inc, Washington, DC.

Krug, B.A., S.E. Burnett, J.H. Dennis, and R.G. Lopez. 2008. Growers look at operating a sustainable greenhouse. GMPro 28:43-45.
Lester, J.P. 1994. A new federalism? Environmental policy in the states, p. 51-68. In: Kraft, M.E. and N.J. Vig (eds.). Environmental policy in the 1990s. Congressional Quarterly, Inc. Washington, DC.

Liao, T.F. 1994. Interpreting probitability models: Logit, probit, and other generalized models. Sage Publications, London, UK.

Lopez, R.G., S.E. Burnett, J.H. Dennis, and B.A Krug. 2008. 8 steps to take to become sustainable. GMPro 28:26-29, 50.

Metcalfe, M. 2000. State legislation regulating animal manure management. Review Agr. De Econ. 22:519-532.

Mo, Y. and C.W. Abdalla. 1998. Analysis of swine industry expansion in the U.S.: The effect of environmental regulation. Staff Paper No. 316, Dept. of Agr. Econ. and Rural Sociology. Pennsylvania State University, University Park, PA.

Morris, C. and C. Potter. 1995. Recruiting the new conservationists: Farmers' adoption of agrienvironmental schemes in the UK. Journal of Rural Studies 11:51-63.

Rogers, E.M. 1962. Diffusion of innovations. The Free Press, New York, NY.

Scarborough, N. and T. Zimmerer. 2006. Effective small business management: An entrepreneur- ial approach. 8th Ed. Pearson Education, Inc., Upper Saddle River, NJ.

Stewart, A. 2007. Flower confidential: The good, the bad, and the beautiful in the business of flowers. Algonquin Books of Chapel Hill, Chapel Hill, NC.

Tambascio, S. 2008. Top 100 growers: Growers taking charge. Greenhouse Grower. 2 June 2008. <http://www.greenhousegrower.com/ specialreports/top $100 /$ storyid $=87>$.

USDA. 2008. Floriculture crops briefing room [archived]: Floriculture crops background; market outlook, trade and policy. 25 July 2008. <http://www.ers.usda.gov/Briefing/ Archive/Floriculture/>.

USDA. 2009. 2007 Census of agriculture: United States: Summary and state data. 1(51). 20 Feb. 2009. <http://www.agcensus.usda.gov/ Publications/2007/Full_Report/usv1.pdf>.

Wilson, G. 1997. Factors influencing farmer participation in the environmentally sensitive area scheme. J. Environ. Manage. 50:67-93.

Woodruff, R. 1997. Customer value: The next source for competitive advantage. J. Acad. Mktg. Sci. 25:139-153.

Zeithamal, V. 1988. Customer perceptions of price, quality, and value: A means-end model and synthesis of evidence. J. Mktg. 52:2-22. 